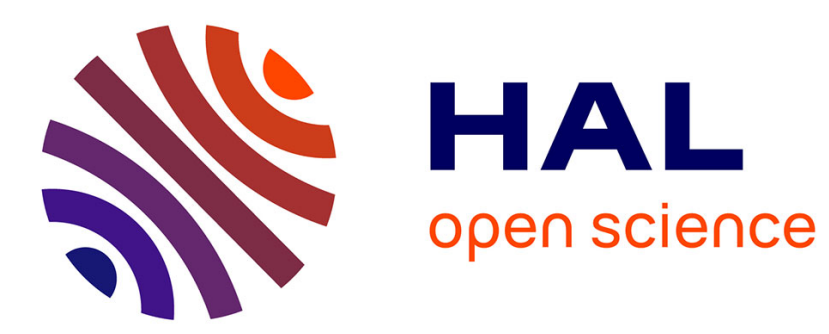

\title{
The Evolution of Decision-Making in the British Labour Party: From Grassroots to Netroots?
}

Emmanuelle Avril

\section{To cite this version:}

Emmanuelle Avril. The Evolution of Decision-Making in the British Labour Party: From Grassroots to Netroots?. Emmanuelle Avril, Christine Zumello New Technologies, Organizational Change and Governance, Palgrave Macmillan, pp.102-117, 2013, 978-1-137-26422-0. 10.1057/9781137264237_7 . hal-01378832

\section{HAL Id: hal-01378832 \\ https://hal.science/hal-01378832}

Submitted on 10 Oct 2016

HAL is a multi-disciplinary open access archive for the deposit and dissemination of scientific research documents, whether they are published or not. The documents may come from teaching and research institutions in France or abroad, or from public or private research centers.
L'archive ouverte pluridisciplinaire HAL, est destinée au dépôt et à la diffusion de documents scientifiques de niveau recherche, publiés ou non, émanant des établissements d'enseignement et de recherche français ou étrangers, des laboratoires publics ou privés. 


\section{7 \\ The Evolution of Decision-Making in the British Labour Party: From Grassroots to Netroots?}

Emmanuelle Avril

When it comes to branding, marketing, and election victories, the revamped British Labour Party, also known as 'New' Labour, undoubtedly stood, until very recently, as a success story which other political parties wished to emulate. However, it is also now a largely discredited organization, which was defeated at the polls in May 2010 and whose members have been leaving in their droves, a disaffection which the 6 per cent post-election surge is unlikely to significantly counter. ${ }^{1}$ It is the contention of this chapter that while the business-inspired reforms account to a large extent for the success of the New Labour brand by raising the organization's responsiveness to a range of stakeholders, such as voters and supporters, who had not previously been prioritized, the modernizers' attachment to a technical, managerial conception of people management contained, from the very start, the seeds of future decay. The lessons drawn from the rise and fall of New Labour therefore provide a unique insight into the potentially disastrous effects of some of the most popular tenets of change management in organizations in general, notably the deleterious impact of the Party's growing disregard for the role of members and activists in achieving the organization's main goals.

This chapter provides an overview of the overall transformation of the Labour Party from a social democratic political party into a marketing organization, through the adoption of change and process management techniques, in which new technologies have come to play a pivotal role. ${ }^{2}$ The transformation of the role of the membership under the combined effects of the Party's structural changes and the development of Internet tools all intended to increase participation and mobilization 
in a context of long-term decline of party membership. ${ }^{3}$ Although 'netroots' is not usually used to refer to party members as such (Netroots UK, for example, aims to 'support the growth of infrastructure, networks and movements for left and centre-left online activism'), the term describes rather well the attempt to move from a formal model of membership (where one pays a fee in exchange for which one is granted certain voting rights) to the much looser model of the 'Supporters Network', attracting supposedly younger, more versatile, and less-demanding voters.

The analysis starts with a brief review of the business-inspired structural changes by which Labour was turned into New Labour, a supposedly more open and more internally democratic political organization; it then focuses on New Labour as a marketing organization whose entire communication strategy, geared to the capture of voters, appears to have been largely misguided; it finally moves to an evaluation of New Labour's tentative use of new technological tools in implementing and communicating change, showing that, despite claims to have cast away the bureaucratic model, the Labour Party can be said to have remained in the thralls of the command-and-control model. New Labour offers therefore the paradox of potentially democratizing tools at the service of increased centralization and control.

\section{From Labour to New Labour: structural changes}

The model which inspired the restructuring of the Labour Party (a process referred to as 'modernization') was borrowed from the business world. The reforms, subsumed in the Partnership in Power policy-making process (Labour Party, 1997a), recently renamed Partnership into Power (Labour Party, 2010) and whose official objective was to 'provide both Labour Party members and non-members with a forum for making their ideas and suggestions heard through discussions at local policy forums and through submissions to Policy Commissions', in fact aimed to establish a business culture at all levels of the Party. The main components of this new culture can be defined as innovation, adaptation, flexibility, as well as a certain idea of the role of leaders and of their relationship with the agents of change within the organization.

The espousal by New Labour of the ideas and values of business did not only translate into the adoption of business-friendly policies; it also led to the adoption of a business-inspired process management aiming to make the Party more responsive to the electoral market. In particular, the structural and procedural reforms turned the Party into a 


\section{PROOF}

more professional organization and consisted in replacing the traditional Labour Party culture by a culture of change embodied by the young and charismatic Tony Blair.

At the beginning of the 1990s, the British Labour Party, which had lost four consecutive elections, undertook reforms aiming at revitalizing the Party, through, among other things, the introduction of deliberation processes in the development of policies and generally more 'direct' relations between the leadership and the wider grassroots (Quinn, 2004; Russell, 2005). However, very few would now disagree that despite the rhetoric of democratization, these reforms were not intended to lead to a reshaping of the internal power equilibrium in favour of grassroots party members, but were, on the contrary, designed to give the leadership significant new powers to control dissent in the Party in a bid to make the Party electable again. In terms of membership, the shift from highly structured and organized grassroots, with a formal and traceable impact on policy formulation, to a looser wider versatile netroots whose influence is much more difficult to pinpoint, mainly to pursue traditional modes of campaigning and electioneering, coincides with a move to dilute the weight of activists within the Party (Farrell and Webb, 2000; Scarrow, 2000).

The official discourse of modernization stressed the necessity for the Party to adopt a decision-making process, which would be more efficient and less off-putting for new and inexperienced members. In practice, it meant greater distance from the trade unions, increased professionalization, and a more disciplined Party (Avril, 2007). The objective of the reforms was a move to a more unified structure, based on a more consensual decision-making process. Changes at the Party's annual conference were particularly significant, this being the highest formal authority in the Party. The widening of consultation also took the shape of a move to the 'one member one vote' (OMOV) to replace the much maligned trade union block vote. What was less noticeable, but just as significant, is that the principle of OMOV was also supposed to apply to constituency delegates at the annual conference who were urged to vote individually and not as a delegation. OMOV was also introduced in the electoral college to elect leaders and the national executive committee, where ballot papers are now sent directly to members' homes instead of a system whereby local parties mandated a delegate to reflect the constituency's majority view in a vote at conference. The new system, although theoretically more 'democratic', is also open to influence by marketing-style campaigns since TV personalities, such as Eastenders actor Michael Cashman or Tony Robinson (also known as Baldric in the 


\section{PROOF}

Emmanuelle Avril 105

Black Adder series), standing for the leadership, tended to score very high votes.

In this way, it was thought the Party would no longer be in the grip of the supposed 'dictatorship' of local activists (Duverger, 1951), since the more inclusive decision-making processes would be open to a larger, but also more malleable, audience, who would be content with episodic consultations. The point was to replace what was a representative model, where power is concentrated in the hands of delegates elected by their peers and who take decisions in the name of their fellow constituency members, with a new and more participative consultation model where the decision-making process would now be open to all members through 'policy forums'.$^{4}$ In practice, therefore, the move towards 'direct democracy' has led to the erosion of the elective power of activists.

Clearly, the idea of increased membership participation does not necessary entail increased membership influence. In fact some have described the emergence of a new ideal-type of political party, called the 'cyber party', where the distinction between members and supporters tends to disappear (Margetts, 2006). The Supporters Network, introduced in 2003 as part of the Big Conversation initiative and described on the Labour Party website as 'a way for people to register their support for Labour without having to join the party', and the internal 'social networking' model Membersnet, defined as 'a tool that helps Labour members and supporters to organize, share and connect', were presented as means to attract those who do not commit to old-style party membership, and are essentially unobtrusive means of gathering data on party members. Peter Mandelson had been quite explicit about the aims of the Partnership in Power reforms when he wrote that 'even if the activists of the past wanted to reassert themselves the new structure of the Party would not permit them to take back control' (Mandelson and Liddle, 1996: 216). Although the National Party's strategy was couched in rather more diplomatic terms in the official party literature, the organizational changes were essentially meant to give the government sufficient room for manoeuvre.

However, orthodoxy and centralized control came with the risk that the Party might find itself cut off from a vital source of innovation and ossify. Although it is obvious that an undisciplined and divided party is almost guaranteed to lose elections, the leadership's exclusive concern for internal cohesion has been potentially even more harmful. The restrictions imposed on internal debate have had a lethal effect on the Party, depriving it of the energy derived from the confrontation of ideas. The environment in which organizations now operate is increasingly 


\section{PROOF}

complex, fluid, and unpredictable and is one where the old organizational models of centralization and top-down decision-making are no longer appropriate. Although some degree of command-and-control is required for any organization to function, the decision-making structures which the New Labour leaders set up seem to go against the new requirements of decentralization and debate.

\section{New Labour as a marketing organization}

New Labour's communication strategy had rested on three main principles which can be summarized as follows: (a) putting the voters at the centre; (b) building consensus around the project; and (c) aligning the internal market to the external market (voters and members are put on the same plane). It is important to bear in mind that the frontiers between the different audiences of New Labour's communication are blurred, the key issue therefore being that of the importance that must be awarded to the voters and to the members, respectively.

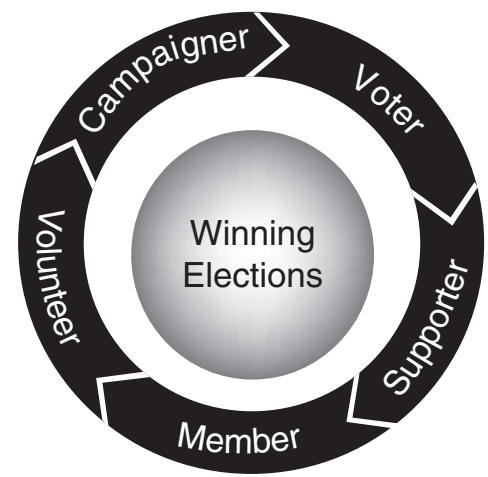

Illustration 7.1 New Labour's communication strategy Source: Adapted from The Labour Party, Building a Healthy Party.

a) Putting the voter at the centre: The marketing approach to politics had led the Labour Party to place the voter at the centre of all their communication effort. In the diagram, 'winning elections' is at the centre; the term 'voter' refers here to Labour voters, whose support has already been secured and who must be persuaded to show greater commitment. This marketing strategy has had a considerable impact on the way the Party operates as an organization. Indeed, the new marketing is not simply about communicating a product efficiently to consumers, it is 
about designing the product to suit consumer's needs and expectations (Lees-Marshment, 2004). The rise of the 'political consumer', whereby consumers in the political markets have become just as demanding as consumers in the commercial market, has been charted by a number of political marketing specialists (for example, Scammell, 2003). A party that tries to emulate marketing organizations will have to follow the rules which apply to the market.

This process of product design started with the Policy Review, launched in 1988 under the leadership of Neil Kinnock, which marked the point where party strategists decided that the formulation of party policy would be determined by the preferences of voters (a strategy known as 'preference accommodating'). This came with the systematic use of 'focus groups'. ${ }^{5}$ The Policy Review thus constituted a turning point showing how much faith was put into marketing tools to guide political choices. The adoption of management models then instituted a culture of quality control and evaluation, which made it imperative for the New Labour government to obtain quantifiable results - to deliver. Understandably, in this model, the essential task of the government is to communicate to voters the result of its action.

The weakness that lay at the heart of the strategy implemented by the modernizers was to concentrate on a specific category of voters which they had identified as key to the project's success. In concentrating exclusively on floating middle-class voters, the leadership became cut off from their traditional supporters, who were considered to be captive voters, without managing to retain the newcomers (Wring, 2005). Therefore the whole of New Labour's communication strategy focused on a relatively narrow segment of the market whose support was conditional upon perceived delivery of quantifiable targets (Lilleker, 2005). As the 2010 election results have shown, New Labour communicated itself into an electoral corner.

b) Building consensus around the project: The structural reforms introduced by the New Labour leadership have consisted in taking decision-making processes away from the annual conference through the creation of multiple consultation arenas and processes. The move away from the traditional decision-making structure naturally led to questioning the centrality of the traditional local party activist. The traditional model of party membership seemed to reflect 'a narrow view' of what constitutes participation and the idea was that moving beyond this uniform model of membership would allow more people to become involved. Attempts to establish 'looser forms of affiliation', or 'a more variable model of 


\section{PROOF}

participation', ${ }^{6}$ via the Supporters Network, would allow people to be associated with the party in new ways.

Advocates of the Supporters Network point to the fact that other organizations manage the duality between members and non-members well, as in the case of football clubs, which have season ticket holders, who make a greater financial and time commitment, and enjoy greater access as a result, and other supporters who play a different role, filling empty seats, advocating the strengths of the team, and providing legitimacy through their numbers. ${ }^{7}$ Other tools included the massive use of 'personalized' emails from the Party's key figures, which created the illusion of a close and direct relationship between leaders and members. Communication through emails was first experimented with during the 2005 campaign with a steady stream of messages stressing the crucial campaigning role played by members, seemingly sent by key political figures and by party officers.

The objective of these new communication tools was to compensate for the decline of traditional sources of commitment by calling upon a much wider base than the usual handful of local activists. Critics have stressed that the Supporters Network is a means to further dilute the influence and legitimacy of paid-up members. Since such 'conversations' have no visible impact on policy formulation, the discussion forums tend to be seen as mere 'talking shops', which do not allow for proper consultation to take place. Activists have complained that they do not want their membership to be on a par with that of some club.

c) Aligning the internal market to the external market: New Labour's organizational reforms aimed at bringing the party into line with the leadership so that local parties could efficiently relay the national message to the voters. The explicit aim of most of the Partnership in Power reforms was to boost members' participation and reinforce the link between party and government so as to 'reconnect' the Party with the voters. Internal communication was therefore designed to get the different elements of the Party to sing the same tune. In fact, one of the major failures of New Labour's communication strategy was precisely in trying to engineer such alignment between the internal and external markets. The problem lies not so much with the marketing techniques themselves as in the fact that the communication strategy did not take the specific nature and motivation of party activism into account. For the overall communication strategy to work, the product must be adjusted both to the external market and to internal demand, which is determined by the Party's history and ideology. With 


\section{PROOF}

Emmanuelle Avril 109

New Labour, it is the party, which was adjusted to the product, with major reforms (such as the rewriting of Clause IV) being announced to the Party without any ground preparation (Lees-Marshment, 2001: 188-189). Overall, the communication model put in place is therefore a one-way, managerial communication model, whose sole aim is to promote the official party line, and in which 'conversations' and 'discussions' have no visible or measurable or traceable impact on policy formulation, rather than a political communication model, based on debate and the confrontation of different viewpoints (Fairclough, 2000).

According to contemporary theories of marketing, in particular the branch known as 'relational marketing' (Christopher et al., 1991), neglecting the internal market can be very hazardous. Whereas classic marketing placed the customer at the centre, in a service society, and all the more so for a political party, the organization's most important audience is its own members: an organization that abandons its internal consumers will progressively lose touch with its clients. The specific requirements of internal branding, however, have been almost completely overlooked by the Labour Party's strategists who, in the words of an ex-Millbank party officer and brand consultant, 'failed to develop a differentiated and internal branding of New Labour, where individual members matter more' ${ }^{8}$ This is reflected for example by the angry reaction of a Labour Party member in a letter to The Guardian in June 2006 in reaction to an invitation by Hazel Blears to a 'Let's Talk session', 'as a member of the Labour Supporters Network': 'This is an entirely spurious exercise. I am not a member of this network. I am a paid-up party member and expect to have the formal structures of the party used to determine party policy'.

New Labour strategists have tended to think of the Party's different audiences as placed on a continuum - from voters, to supporters, to members, to activists, who can only be told apart by the intensity of their commitment. The party literature, subsumed in Illustration 7.1 shown earlier, provides no explanation as to what the Party can do to motivate members to become 'campaigners', the category showing the highest level of involvement. In fact the effort made by New Labour to accommodate the needs and expectations of the different audiences has been in reverse proportion to their level of commitment to the Party. More worryingly, such a Russian-doll view rests upon a misconception of what urges citizens to join and what motivates members to be active, in particular an underestimation of the importance of the expressive function of membership (Kirchheimer, 1966; Panebianco, 1988: 268; Katz and Mair, 1995). There is a substantial, qualitative difference between 


\section{PROOF}

110 Breaking Organizational Boundaries

voters, supporters, and members, which calls for the adoption of specific communication strategies.

\section{New Labour's use of new technologies}

When it comes to evaluating the impact of new technologies on political parties, research carried out on the involvement of online party members has shown that the new tools have the potential to both widen and deepen participation: they help increase numbers and broaden the membership profile, while providing new channels for member-to-member as well as member-to-elites communication (Ward et al., 2002). However, the use of new technologies by the Labour Party has tended to reflect the managerial approach described previously, that is to say with the aim to improve existing top-down one-way processes rather than establishing new more lateral collaborative ones.

This is reflected in the essentially one-dimensional configuration of the Party's website where exchanges, when they do exist, remain very limited and centrally controlled. In the Membersnet area, ${ }^{9}$ the 'Discuss' tab gives a list of forums for online debate on large areas of policy ('Crime \& Justice', 'Britain in the world', etc.) but all the groups are tagged as 'Party Generated Groups' with discussion points such as 'How do we tackle new global security challenges?' or 'How do we tackle the challenges posed by climate change?'. Under the same 'Discuss' tab, there is also a blog section giving a list of all the individual members' blogs created, which might give at first an impression of a very active online debate, while in fact the 92 pages (which would mean a total of over 1,800 blogs) are actually only 59 pages, the rest being blank, and only the first few pages list active blogs, although most only have between one to five posts on them. By Page 5 one finds blogs that have not been updated for a whole month, by page 11 one reaches blogs that have remained inactive for three months, and at the bottom of the list there are blogs that have not been updated for four years, presumably since the day they were created. Under the 'Groups' tab, about 160 public discussion groups are found, most but not all created by individual members, from 'Anglo-Catholic Socialists' to 'Vote for the under 18' to 'Keep the fox hunting ban' - these groups have managed to attract no more than a couple of hundred people each. In the same section, the 'Change We See' group is in fact a party-generated group which became active during the 2010 election campaign, especially on Facebook, and is the only example of an official crowdsourcing experiment, where 


\section{PROOF}

Emmanuelle Avril 111

members are supposed to upload photos of improvements brought to their neighbourhood under Labour.

In fact the most useful and popular sections are those where members may print off or send the latest campaigning poster, download campaigning user guides and toolkits, and access the Virtual Phone Bank. The website is as yet essentially a cheaper extension of advertising campaigns as well as a fundraising tool. Undeniably, the new campaigning tools, some of which were put to the test for the first time by local party activists in the May 2010 election (Avril, 2011), are impressively efficient. However, there is no real sign of a qualitative leap. For example, access to the Membersnet area on the Party's website was long restricted to paid up members, which meant that they were the only ones able to use campaigning tools such as the Virtual Phonebank. Despite the promise held in the terminology, the recent launch of Labour Unlocked, which allows members and supporters to log in to all Labour-related sites, is about aggregating diverse websites but does not yet allow to properly tap into the looser network of supporters the Party has sought to build over the past few years. In November 2011, NEC member Peter Kenyon made the comment on his blog that 'remarkably little thought or effort appears to have been put into a radical overhaul of these facilities to enable the member friendly, inclusive, outward looking party some of us have aspired to for decades'.$^{10}$ Revealingly, the Partnership into Power review document asks the very revealing question: 'What more can we do to involve and engage expert opinion?' (Labour Party, 2010: 10). There is therefore no notion as yet of the potential of the Internet precisely to be a source of collaborative networking.

The fact remains that the rise of social networking, where supporters talk to supporters, as opposed to the one-way announcement format between campaign and supporter, could have a far-reaching impact. Labour's website has taken a few cautious steps in that direction, as is shown above. This kind of social media strategy, if it genuinely allows member-to-member contact, can be far more useful in keeping people interested than trying to attract thousands of people to be 'friends' of the Prime Minister or party leader on a Facebook page. Membersnet was described by a Labour blogger as 'a clear example of a powerful tool waiting for people to unleash its potential'. However, this means losing control of the content generated on these new channels, a step the Labour Party (as all British parties) is not prepared to take, for fear of what might happen if they set up truly open interactive platforms.

The great - and mostly verified - worry is that social media may turn the Party into an object of ridicule, as any gaffe is likely to go viral in 


\section{PROOF}

112 Breaking Organizational Boundaries

a matter of minutes. As can be expected, the results when searching for Gordon Brown videos on YouTube are several films of his 'bigot campaign gaffe'. The first results for Ed Miliband as of March 2012 are two sessions in the House of Commons, his Local Election speech, and the embarrassing video of his 30 June 2011 BBC interview about public sector strikes during which he was caught repeating the same line over and over. ${ }^{11}$ There are also fears of 'entryism', or misuse by opponents, should campaigning tools such as the virtual phone bank be open to all, hence the very stringent terms of service. ${ }^{12}$ The only true example of successful crowdsourcing was the spoof poster website mydavidcameron which became one of the main stories of the 2010 election campaign and illustrated the potential of collaborative environments to enthuse the public.

But over-timid use of the new technologies available, which tend to be seen more as campaign tools rather than offering an opportunity for real debate, can also have highly detrimental effects. First, they are not really attractive to the wider public. Overall very few people in Britain watch political parties' videos: to date, the total number of views for the 474 videos on the Labour Party's YouTube channel (theuklabourparty) stands at 2,231,477, which is modest when considering that videos of the top pop stars have long passed the 1 billion mark. While one of Lady Gaga's video, Bad Romance, stands at 459 million views, one of the most popular videos on the Labour Party channel, such as Ed Miliband's acceptance speech at the 2010 annual conference, has reached a little under 19,000 views. The election manifesto was a hit with over 140,000 views to date - again a paltry score compared to the YesWeCan video of the 2008 Obama campaign, which had reached 4 million views in just ten days (it now stands at about 14 million).

The interactivity of the channel leaves a lot to be desired when by 'taking part in Q\&As' what is meant is that you will be able to view videos of ministers supposedly responding to questions sent via the website ('Ed Balls answers your questions'). Facebook is also mainly used as a broadcasting tool as nearly all posts on the Labour Party page, ${ }^{13}$ which is described as a place where 'you can keep up to date and talk with other supporters', are official posts, the 'debate' being relegated to the comments. The LabourList page, ${ }^{14}$ which is presented as 'the online forum for Labour minded people to come together to discuss news and progressive values' and claims to encourage debate within the Party is in fact mainly another platform of support for the leadership. This is unlikely to change since, in the Partnership into Power review document, the section devoted to technology, which is relegated to the very end, is only three

February 16, 2013 13:1 MAC/AVRIL Page-112 9781137264220_08_cha07 


\section{PROOF}

Emmanuelle Avril 113

lines long (out of 17 pages) with the discussion point being 'How, if at all, technology could be used to disseminate information about the process?' The main blind spot of the marketing approach is that it does not understand a communication process that involves talking and listening at the same time (Coleman, 2005).

Therefore, although new media are touted as tools of democratization and empowerment, technology is not in itself a stimulus to participation; there is no guarantee that the use of new social media, especially not if they are used just as another marketing channel, will increase participatory democracy within parties. Overall, the new media potentially make it easier for parties to market themselves to the already sympathetic but will not be able to reverse the long-term trend of declining membership, as empirical evidence indicates that parties are not using the technology to reinvent mass participation but only to improve campaign efficiency (Jackson and Lilleker, 2009). For the time being, Labour's use of technological tools seems simply to enhance existing trends of internal centralization and individualization. Since the agenda and resources are controlled top-down, the party leadership tends to use them to legitimize their position and maximize support for the leadership's line through plebiscitary votes rather than to build meaningful member-to-member contact. One can consider along with Patrick Seyd and Paul Whiteley that the structure of the Labour Party has evolved towards a 'plebiscitary' model, characterized by 'a veneer of democracy disguising centralization and control' (Seyd and Whiteley, 2002: 176), in complete opposition with the participative model, which would help get activists back on the campaign trail.

\section{Conclusion}

Election failure and membership decline show that Labour's attempts at reforming membership have failed to produce the kind of 'vibrant' organization which the official party literature had promised to deliver. This is because the changes brought to the Party's structure rested upon a misconception of the human dimension both of organizational change and of politics, as well as on a misunderstanding and misuse of the technical means available, in particular the potential of the new technologies to establish collaborative environments and foster lateral communication in place of the top-down, hierarchical model. The flow of communication has in fact firmly remained in the hands of the leadership, leaving very little room, if any, to debate, in spite of the multiplication of participative forums both offline and online. 


\section{PROOF}

\section{Breaking Organizational Boundaries}

The dilemma of efficient management, or management focused on the short-term needs of customers and on improving the product, is that it often turns out to be the very cause of eventual failure, since the qualities required for innovation are flexibility and adaptability (Christensen, 2000). The growing uncertainty of the working environment of businesses finds an echo in politics where the effects of globalization and technological change are also felt. Both the commercial and political clienteles are proving increasingly difficult to attract. This calls for a reevaluation of traditional managerial practices based on a mechanistic conception of organizations and on an ideology of consensus. The new management, as advocated by its supporters, posits that the creative capacity of individuals within an organization is the condition for its survival.

Although the dividends of a more professional approach seem obvious, one of the main effects of the emphasis on process management within the Labour Party has been to produce an increasingly standardized model of rules and behaviours that lacks the flexibility required for creative and innovative practices. This flaw of the New Labour project was acknowledged in the 2011 Refounding Labour Report, which recommended structural changes in recognition that 'no one size fits all' (Labour Party, 2011). This could indicate a realization among Labour strategists of the necessity to move beyond the marketing model that has prevailed so far. The developing 'architecture of participation'15 and the disruptive power of the social media, whose content is usergenerated and cannot be centrally controlled, may well force, in time, a change from the bottom up.

\section{Notes}

1. According to an internal memo leaked to Sam Coates at The Times in January 2012, the Labour Party membership has grown by 65,000 since the election (document reproduced on twitter https://twitter.com/\#!/SamCoatesTimes/ status/154905476453244928/photo/1). Previous figures had shown plummeting membership, down to a low of 176,891 at the end of 2007 , according to figures given to the electoral commission, despite the successful recruitment drive which had taken the membership to a record high of 405,000 following the 1997 victory. What the declining membership shows is that New Labour was not able to retain the new categories of members it had first attracted to join.

2. The analysis provided in this chapter is based on participant observation of annual conferences, election campaigns, local parties, and extensive interviews at all levels of the Labour Party, conducted over the past two decades. 
3. Comparative studies (for example, Mair and van Biezen, 2001) carried out in advanced industrial societies reveal a long term membership decline from the 1960s, even though some parties, such as New Labour in the late 1990s, have occasionally reversed the trend over shorter periods.

4. Policy forums were set up in order to diminish the centrality of the annual conference in the policy-making process and to foster a more consensual approach. The Partnership into Power internal document insists upon a consultation process which ensures 'maximum participation by all stakeholders' (Labour Party, 2010: 7).

5. Focus Groups were first used as a research tool in sociology and social psychology, to complement qualitative methods, and were later adopted in marketing and product design (Merton and Kendall, 1946; Krueger and Casey, 2000).

6. The expressions are from Young Fabian researcher Jessica Studdert, in a post for Progress Online, 1 September 2007. URL: http://www.progressonline.org. uk2007/09/01/inside-out/

7. Ibid.

8. Joe Goldberg, 'Office Politics', Progress Online, 6 June 2002. URL: http:// www.progressonline.org.uk/2002/06/06/office-politics/ [last accessed 14 May 2012].

9. Details of the data available on Membersnet cited in this section were collected in early 2011.

10. http://petergkenyon.typepad.com/peterkenyon/2011/11/index.html

11. Video available at http://www.bbc.co.uk/news/uk-politics-13971770

12. Unlock Labour Terms of service available at http://unlock.labour.org.uk/ termsofservice

13. https://www.facebook.com/labourparty

14. https://www.facebook.com/LabourList

15. The expression is borrowed from Tim O'Reilly's famous definition of the value of the World Wide Web as being created by its users, which was itself mainly inspired from Larry Lessig.

\section{Bibliography}

Avril, E. (2007). Du Labour au New Labour. Le changement vu de l'intérieur, Lille: Presses Universitaires du Septentrion.

Avril, E. (2011). 'Word of mouth, word of mouse: la campagne des Travaillistes à l'heure des "premières élections numériques » en Grande-Bretagne', in Avril, E. and Schnapper, P. (eds.), Les Elections législatives britanniques de 2010, Revue Française de Civilisation Britannique, 16(1), Spring 2011: 35-45.

Christensen, C. (2000). The Innovator's Dilemma, New York, NY: HarperBusiness Essentials.

Christopher, M., Payne, A., and Ballantyne, D. (1991). Relationship Marketing: Bringing Quality, Customer Service and Marketing Together, Oxford: Butterworth Heinemann.

Coleman, S. (2005). 'New Mediation and Direct Representation: Reconceptualising Representation in the Digital Age', New Media \& Society, 7(2): 177-198.

Duverger, M. (1951). Les Partis politiques, Paris: Armand Colin. 
Fairclough, N. (2000). New Labour, New Language?, London: Routledge.

Farrell, D., and Webb, P. (2000). 'Political Parties as Campaign Organizations', in Dalton, R. And Wattenberg, M. (eds.), Parties Without Partisans, Oxford: Oxford University Press, pp. 102-128.

Gibson, R., and Ward, S. (2000). 'A Proposed Methodology for Measuring the Function and Effectiveness of Political Web-Sites', Social Science Computer Review, 18(3): 301-319.

Hoff, J., Horrocks, I., and Tops, P.W. (2000). Democratic Governance and New Technology. Technologically Mediated Innovations, London: Routledge.

Jackson, N. and Lilleker, D. (2009). 'Building an Architecture of Participation?: Political Parties and Web 2.0 in Britain', Journal of Information Technology and Politics, 6(3/4): 232-250.

Katz, R.S. and Crotty, W.J. (2006). Handbook of Party Politics, London: Sage.

Katz, R.S. and Mair, P. (1995). 'Changing Models of Party Organization and Party Democracy: the Emergence of the Cartel Party', Party Politics, 1(1): 5-28.

Kirchheimer, O. (1966). 'The Transformation of the Western European Party Systems', in Lapalombara, J. and Weiner, M. (eds.), Political Parties and Political Development, Princeton, NJ: Princeton University Press.

Krueger, R.A. and Casey, M.-A. (2000). Focus Groups: A Practical Guide for Applied Research, Thousand Oaks, CA: Sage.

LABOUR PARTY (1997a). Partnership in Power. Policy Making Process.

LABOUR PARTY (1997b). Building a Healthy Party.

LABOUR PARTY (2010). Partnership into Power. Review of Labour Party Policy Making.

LABOUR PARTY (2011). Refounding Labour to Win. A Party for the New Generation.

Lees-Marshment, J. (2001). Political Marketing and British Political Parties: the Party's Just Begun, Manchester: Manchester University Press.

Lees-Marshment, J. (2004). The Political Marketing Revolution, Manchester: Manchester University Press.

Lessig, L. (1999). Code and Other Laws of Cyberspace, New York, NY: Basic Books.

Lilleker, D. (2005). 'Political Marketing: The Cause of an Emerging Democratic Deficit in Britain?' in Wymer, W. Jr. and Lees-Marshment, J. (eds.), Current Issues in Political Marketing, Binghamton, NY: Haworth Press, pp. 5-26.

Lusoli, W. and Ward, S. (2003). 'Digital Rank-and-File: Party Activists' Perceptions and Use of the Internet', Paper given at the Annual Meeting of the American Political Science Association, Philadelphia, PA.

Mair, P. and van Biezen, I. (2001). 'Party Membership in Twenty European Democracies', Party Politics, 7(1): 5-21.

Mandelson, P., and Liddle, R. (1996). The Blair Revolution: Can New Labour Deliver? London: Faber \& Faber.

Margetts, H. (2006). 'The Cyber Parties', in Katz, R.S. and Crotty, W.J. (eds.), Handbook of Party Politics, London: Sage, pp. 528-535.

Merton, R.K. and Kendall, P.L. (1946). 'The Focused Interview', American Journal of Sociology, 51: 541-557.

Norris, P., Curtice, J., et al. (1999). On Message. Communicating the Campaign, London: Sage.

Panebianco, A. (1988). Political Parties: Organization and Power, Cambridge: Cambridge University Press. 
Quinn, T. (2004). Modernising the Labour Party. Organizational Change since 1983, Basingstoke: Palgrave Macmillan.

Russell, M. (2005). Building New Labour: The Politics of Party Organization, Basingstoke: Palgrave Macmillan.

Scammell, M. (1999). 'Political Marketing: Lessons for Political Science', Political Studies, XLVII: 718-739.

Scammell, M. (2003). 'Citizen Consumers: Towards a New Marketing of Politics?' in Corner, J. and Pels, D. (eds.), Media and the Restyling of Politics: Consumerism, Celebrity, Cynicism, London: Sage, pp. 117-136.

Scarrow, S. (1994). "The "Paradox of Enrolment": Assessing the Costs and Benefits of Party Memberships', European Journal of Political Research, 25(1): 41-60.

Scarrow, S. (2000). 'Parties without Members? Party Organization in a Changing Electoral Environment', in Dalton, R. and Wattenberg, M. (eds.), Parties Without Partisans, Oxford: Oxford University Press, pp. 79-101.

Scarrow, S. (2005a). 'Political Parties and Democracy: Theoretical and Practical Perspectives', National Democratic Institute for International Affairs, Implementing Intra-Party Democracy.

Scarrow, S. (2005b). Implementing Intra-Party Democracy (Political Parties and Democracy in Theoretical Perspectives Series), Washington, DC: NDI.

Seyd, P., and Whiteley, P. (2002). New Labour's Grassroots: The Transformation of the Labour Party Membership, Basingstoke: Palgrave Macmillan.

Ward, S., Lusoli, W., and Gibson, R. (2002). 'Virtually Participating: A Survey of Online Party Members', Information Polity, 7: 199-215.

Whiteley, P. and Seyd, P. (1998). 'The Dynamics of Party Activism in Britain: A Spiral of Demobilization?', British Journal of Political Science, 28: 113-137.

Wring, D. (2005). The Politics of Marketing the Labour Party, Basingstoke: Palgrave Macmillan. 